\title{
Optimizing Row Spacing to Ameliorate the Productivity of Spring Sugarcane (Saccharum officinarum L.)
}

\author{
Sami Ullah 1,2, Shakeel Ahmad Anjum 1*, Muhammad Mohsin Raza ${ }^{3}$, Aamir Riaz1, \\ Adeel Abbas', Malik Muhammad Yousif's, Jinchuan Ma², Yingxia Liư ${ }^{5}$, Jiajia Zhang2, \\ Dingwen Cheng' ${ }^{2}$ Yaxin $\mathrm{Xu}^{5}$, Iftikhar Ali ${ }^{1}$ \\ ${ }^{1}$ Department of Agronomy, University of Agriculture Faisalabad, Faisalabad, Pakistan \\ ${ }^{2}$ Ministry of Agricultural Key Laboratory of Crop Nutrition and Fertilization, Institute of Agricultural \\ Resources and Regional Planning, Chinese Academy of Agricultural Sciences, Beijing, China \\ ${ }^{3}$ Arid Zone Research Institute, Pakistan Agriculture Research Council, Bahawalpur, Pakistan \\ ${ }^{4}$ Weed Science Laboratory, Institute of Plant Protection, Chinese Academy of Agricultural Sciences, \\ Beijing, China \\ ${ }^{5}$ College of Resource and Environment, Jilin Agricultural University, Changchun, China \\ Email: "shakeelanjum1034@gmail.com
}

Received 3 August 2016; accepted 22 August 2016; published 25 August 2016

Copyright (C) 2016 by authors and Scientific Research Publishing Inc.

This work is licensed under the Creative Commons Attribution International License (CC BY).

http://creativecommons.org/licenses/by/4.0/

(c) (i) Open Access

\section{Abstract}

One of the main reasons behind reduced cane yield is pathetic method of planting. Planting method and row spacing are the most important yield contributing factors in sugarcane. A field experiment was carried out in order to determine quality and yield of sugarcane in various spatial arrangements. Treatments are $180 \mathrm{~cm}$ spaced trenches with triple row strips; $180 \mathrm{~cm}$ spaced trenches with alternate row strips; $120 \mathrm{~cm}$ spaced trenches with double row strips and $60 \mathrm{~cm}$ spaced furrow with single row. Perusal of data revealed that $3.6 \%, 13.4 \%, 15 \%, 15.3 \%$ more cane diameter $(\mathrm{cm})$, cane length $(\mathrm{cm})$, stripped cane yield $\left(\mathrm{t} \cdot \mathrm{ha}^{-1}\right)$, sugar yield $\left(\mathrm{t} \cdot \mathrm{ha}^{-1}\right)$ were obtained from $180 \mathrm{~cm}$ spaced trenches with triple row strips as compared to conventional planting method i.e. $60 \mathrm{~cm}$ spaced furrows. While the number of millable canes $\mathrm{m}^{-2}$, polarity \%, cane juice purity \%, cane juice \%, commercial cane sugar $\%$ and cane sugar recovery $\%$ remained non-significant by different planting techniques.

\section{Keywords}

Furrow Planting, Quality, Row Spacing, Sugarcane, Trench Planting, Yield

\footnotetext{
${ }^{*}$ Corresponding author.
}

How to cite this paper: Ullah, S., Anjum, S.A., Raza, M.M., Riaz, A., Abbas, A., Yousif, M.M., Ma, J.C., Liu, Y.X., Zhang, J.J., Cheng, D.W., Xu, Y.X. and Ali, I. (2016) Optimizing Row Spacing to Amelioratethe Productivity of Spring Sugarcane (Saccharum officinarum L.). Agricultural Sciences, 7, 531-538. http://dx.doi.org/10.4236/as.2016.78053 


\section{Introduction}

Sugarcane (Saccharum officinarum L.) is regarded as an important cash crop of Pakistan. The crop was cultivated at an area of 1141 thousand hectares with total production of 62.7 million tons during 2014-2015 [1]. Average yield of sugarcane in Pakistan is $56.7 \mathrm{t} \cdot \mathrm{ha}^{-1}$ [1], considerably lower than world's leading sugarcane producing countries like Australia, Brazil, the USA, China and India, having average yield 80.39, 78.85, 77.63, 64.49 and $68.08 \mathrm{t} \cdot \mathrm{ha}^{-1}$, respectively [2].

There are many reasons behind reduced cane yield and sucrose contents, such as Pakistan is not situated in tropical area where sugarcane performs best, two-thirds area of sugarcane is located in the north part of country where in winter frost occurs and frost plays destructive role in cane yield [3]. Moreover expensive inputs, poor fertilizer application method, natural calamities [4], delayed harvesting, insufficient irrigation water, heavy weed infestation [5], poor management of ratoon and planting geometry are some of the reasons of low yield of sugarcane [6].

Now the debate comes up with the planting geometry since planting geometry plays important role in water use efficiency, interception of solar radiation and evaporation. Row spacing is considered to be the most important planting geometry parameter in sugarcane. Row spacing ensures more uniform allocation of plants in an area and makes canopy of plant more efficient in intercepting radiant energy [3]. In Pakistan different sowing methods are being used for enhancement in sugarcane yield. Most of the farmers used conventional planting method like 60 to $75 \mathrm{~cm}$ apart furrows which are helpful in more plant population per unit area to some extent but it results problems in management operations like interculture, air circulation and light interception which are very important factors for good crop yield [7].

A new approach for ameliorating sugarcane yield is "trench planting” with double and triple row strips. Trench planting can be attained by placing the setts in trenches at the depth of $30-45 \mathrm{~cm}$. Trench planting system has proved more suitable and effective planting system than conventional planting system. Sugarcane planted in trenches with optimum seed rate produced more returns than conventional systems [7]. Nowadays dwindling natural resources especially irrigational water is of key concern. Planting sugarcane in trenches can save irrigation water up to $20 \%$ [8]. Furthermore cane planted in $120 \mathrm{~cm}$ apart trenches produced $30 \%$ more yield than conventional planting [8]. In the light of above discussion this study was formulated to determine the cane quality and yield in different row spacing/planting techniques.

\section{Materials and Methods}

\subsection{Site}

The present study was conducted at Agronomic Research Area, Department of Agronomy, University of Agriculture Faisalabad during spring 2014. Faisalabad is situated on $31.41^{\circ} \mathrm{N}$ and $73.07^{\circ} \mathrm{E}$. The altitude of Faisalabad is $184 \mathrm{~m}$ above sea level. The soil of the district, Faisalabad, is alluvial plain formed by the rivers: Chenab and Ravi. The area is irrigated by perennial canals. The district has extremes of climate. The summer season starts from April and continues till October while May, June, and July are the hottest months of the year. The mean maximum and minimum temperature in summer are $39^{\circ} \mathrm{C}$ and $27^{\circ} \mathrm{C}$, respectively. The winter season starts from November and continues till March. December, January, and February are the coldest months of the year. The mean maximum and minimum temperature during this period are $21^{\circ} \mathrm{C}$ and $6^{\circ} \mathrm{C}$, respectively.

\subsection{Experimental Material}

The Experiment was comprised of four treatments i.e. $180 \mathrm{~cm}$ spaced trenches with triple row strips; $180 \mathrm{~cm}$ spaced trenches with alternate row strips; $120 \mathrm{~cm}$ spaced trenches with double row strips and $60 \mathrm{~cm}$ spaced furrow with single row. The field was well prepared before seed bed preparation. Land was levelled with the help of laser land leveller. Trenches were made with ridger. All other agronomic practices were kept normal and uniform for all the treatments. The sugarcane variety HSF-240 was used as experimental material. The cultivar was obtained from Sugarcane Research Institute, Ayub Agricuture Research Institute (AARI), Faisalabad, Pakistan. The seed rate was 75,000 double budded setts $\mathrm{ha}^{-1}$ to sow the crop. The sugarcane was planted on the $21^{\text {st }}$ of March 2014. Fertilizer was applied @ $175 \mathrm{~kg} \cdot \mathrm{N}, 115 \mathrm{~kg} \cdot \mathrm{P}_{2} \mathrm{O}_{5}$, and $115 \mathrm{~kg} \cdot \mathrm{K}_{2} \mathrm{O} \cdot \mathrm{ha}^{-1}$ Ghaffar (2011) in the form of Urea, DAP, and SOP, respectively. The whole $\mathrm{P}, \mathrm{K}$, and $1 / 3^{\text {rd }}$ of $\mathrm{N}$ were applied as a basal dose at the time of sowing, while remaining $N$ was applied in two splits, $1 / 3^{\text {rd }}$ at the start of tillering and $1 / 3^{\text {rd }}$ before earthing up by side dressing. Earthing up of sugarcane was done 90 days after planting. Weeds in the crop were controlled 
through the application of Ametryn + Atrazine @ $2.5 \mathrm{~kg} \cdot \mathrm{ha}^{-1}$ five days after first irrigation with a knapsack sprayer and also with interculture. Insect pests were kept under the threshold level through chemical control. Chloropyrihos was applied at the rate of $5 \mathrm{~L} \cdot \mathrm{ha}^{-1}$ with first irrigation after sowing for the control the termites. Carbofuran granules at the rate of $35 \mathrm{~kg} \cdot \mathrm{ha}^{-1}$ were applied at earthing up stage to control borers. A total of $16 \mathrm{ir}-$ rigations were applied to the crop as and when needed. The amount of irrigation water received by the crop of the experiment during the year was also supplemented by rainfall that was $367 \mathrm{~mm}$. Total water received was $1967 \mathrm{~mm}$ (Irrigation + Rainfall). The crop was harvested manually after its maturity on $5^{\text {th }}$ of March 2015.

\section{Procedures and Formulas for Recording Observations}

\subsection{Millable Canes}

Millable canes refer to the canes that have attained normal height and thickness at their physiological maturity and are ready to harvest for processing. Number of millable canes in each experimental unit was counted at harvest and then converted into number of millable canes per $\mathrm{m}^{2}$.

\subsection{Cane Length}

At harvest length of ten randomly selected stripped canes from each experimental unit was measured $(\mathrm{cm})$ from base to top and then averaged.

\subsection{Cane Diameter}

Ten canes were randomly selected from each experimental unit and diameter of each cane from the bottom, middle and top was measured with a vernier caliper. The average of these values was taken as cane diameter.

\subsection{Stripped Cane Yield}

All stripped canes from each experimental unit were weighed and transformed to tons per hectare.

\subsection{Brix}

Ten randomly selected canes from every plot were crushed through a cane crusher and the juice was collected in glass jars. The reading of brix (\%) was recorded with Brix hydrometer. Temperature of the juice was noted. These brix readings were corrected with the help of Schmitz's table [9].

\subsection{Polarity}

With the help of polarimeter, pol reading of extracted juice of every treatment was recorded. Sucrose contents of cane juice were calculated with the help of Schmitz's table [9].

\subsection{Cane Juice Purity}

Cane juice purity was determined as described by [9].

$$
\text { Cane juice purity }(\%)=\frac{\text { Pol percent juice }}{\text { Brix percent juice }} \times 100
$$

\subsection{Cane Juice Percent}

Cane juice (\%) for each treatment was determined as follows:

$$
\text { Extracted cane juice }(\%)=\frac{\text { Weight of juice }(\mathrm{kg})}{\text { Weight of stripped cane }(\mathrm{kg})} \times 100
$$

\subsection{Commercial Cane Sugar}

Commercial cane sugar (CCS \%) was calculated by using the method of [9]. 


$$
\operatorname{CCS}(\%)=\frac{3}{2} P\left(1-\frac{\mathrm{F}+5}{100}\right)-\frac{1}{2} B\left(1-\frac{\mathrm{F}+3}{100}\right)
$$

where $P=\operatorname{Pol} \%$ in juice, $B=$ Brix \% in juice, $F=$ Fiber $\%$ in juice $(12.5 \%)$.

\subsection{Cane Sugar Recovery Percentage}

Cane sugar recovery percent was calculated by following formula:

$$
\operatorname{CSR}(\%)=\operatorname{CCS}(\%) \times 0.94
$$

where CCS is commercial cane sugar, and 0.94 is net titer (sugar losses).

\subsection{Sugar Yield}

Sugar yield $\left(\mathrm{t} \cdot \mathrm{ha}^{-1}\right)$ was determined by the following formula:

$$
\text { Sugar yield }\left(\mathrm{t} \cdot \mathrm{ha}^{-1}\right)=\frac{\text { Stripped cane yield } \mathrm{t} \cdot \mathrm{ha}^{-1}}{100} \times \mathrm{CCS} \%
$$

\subsection{Statistical Analysis}

Data recorded on each parameter was tabulated and analyzed statistically by using Fisher's Analysis of Variance technique. Least significant difference (LSD) test at 5\% probability was used to compare the difference amongst treatment means [10]. Computer software program MSTATC was used for this purpose. The computer package MS Excel was used to prepare the graphs.

\section{Results and Discussions}

\subsection{Number of Millable Canes}

Millable canes per unit area are the major yield contributing parameter of sugarcane. Millable canes at harvest (Table 1) were not significantly affected by different planting pattern which on the average ranged from 11.12 to 12.80. Our results are similar with those of [7] [11], they revealed millable canes were not significantly influenced by planting techniques. Regression model is shown in Figure 1.

\subsection{Cane Length}

Cane length is a major yield contributing factor in sugarcane. Data regarding cane length is presented in Table 1 which revealed that different planting configurations influenced the cane length significantly. Statistically maximum cane length $224 \mathrm{~cm}$ was recorded in sugarcane planted at $180 \mathrm{~cm}$ spaced trenches with triple row strips. Sugarcane planted at $120 \mathrm{~cm}$ spaced trenches with double row strips produced cane length of $212 \mathrm{~cm}$ which was statistically at par with $180 \mathrm{~cm}$ spaced trenches with alternate row strips $208 \mathrm{~cm}$. Plants with lower

\begin{tabular}{|c|c|c|c|c|c|}
\hline Treatments & $\begin{array}{l}\text { No. of millable } \\
\text { canes }\left(\mathrm{m}^{-2}\right)\end{array}$ & $\begin{array}{l}\text { Cane length } \\
\text { (cm) }\end{array}$ & $\begin{array}{l}\text { Cane diameter } \\
\text { (cm) }\end{array}$ & $\begin{array}{l}\text { Stripped cane } \\
\text { yield }\left(t \cdot h a^{-1}\right)\end{array}$ & Brix \% \\
\hline $\begin{array}{l}180 \mathrm{~cm} \text { spaced trenches } \\
\text { with triple row strips. }\end{array}$ & 12.80 & $224 \mathrm{~A}$ & $2.50 \mathrm{~A}$ & $107 \mathrm{~A}$ & 21.85 \\
\hline $\begin{array}{l}180 \mathrm{~cm} \text { spaced trenches } \\
\text { with alternate row strips. }\end{array}$ & 12.02 & 208 B & $2.45 \mathrm{~B}$ & $99 \mathrm{C}$ & 21.51 \\
\hline $\begin{array}{l}120 \mathrm{~cm} \text { spaced trenches } \\
\text { with double row strips. }\end{array}$ & 12.30 & $212 \mathrm{~B}$ & $2.46 \mathrm{~B}$ & $102.25 \mathrm{~B}$ & 21.75 \\
\hline $\begin{array}{l}60 \mathrm{~cm} \text { spaced furrow } \\
\text { with single row. }\end{array}$ & 11.12 & $194 \mathrm{C}$ & $2.41 \mathrm{C}$ & $91 \mathrm{D}$ & 21.65 \\
\hline LSD $@ \mathrm{P} \leq 0.05$ & NS & 6.11 & 2.80 & 1.36 & NS \\
\hline
\end{tabular}
cane length $194 \mathrm{~cm}$ were produced in $60 \mathrm{~cm}$ spaced furrow with single row.

Table 1. Effect of Effect of planting techniques on millable canes, cane length, cane diameter, stripped cane yield and brix.

NS = Non Significant. Letters A,B,C,D represents significant results. A means highest obtained value while D means lowest obtained value. A, B, C, $\mathrm{D}$ follows descending order in terms of values $(\mathrm{A}>\mathrm{B}>\mathrm{C}>\mathrm{D})$. 
More cane length in $180 \mathrm{~cm}$ spaced trenches might be due to better light penetration into the crop canopy and cross-air circulation because of wider spacing. More cane length at wider row spacing is also ascribed to higher light interception, better utilization of nutrients and water that might be resulted in increased crop growth rate which finally produced longer canes. While less cane length in case of $180 \mathrm{~cm}$ spaced trenches with alternate row strips might be due to less utilization of nutrients and water, less space because of dense plant population [12] [13] also reported cane height increases in wider rows compared with narrow row spacing. Regression model is indicated in Figure 2.

\subsection{Cane Diameter}

Perusal of data regarding cane diameter showed significant variation for cane diameter under different planting configurations (Table 1). Statistically maximum cane diameter $2.5 \mathrm{~cm}$ was observed in $180 \mathrm{~cm}$ spaced trenches with triple row strips. Sugarcane planted in $120 \mathrm{~cm}$ spaced trenches with double row produced cane diameter $2.46 \mathrm{~cm}$ which was statistically at par with cane planted in $180 \mathrm{~cm}$ spaced trenches with alternate row strips produced cane diameter $2.45 \mathrm{~cm}$. While $60 \mathrm{~cm}$ spaced furrow with single row strips produced minimum cane diameter $2.41 \mathrm{~cm}$. Difference in cane diameter is might be ascribed to variable number of canes per square meter. More cane diameter in wider rows might be attributed to better uptake of water and nutrients, more light penetration and cross air circulation. Lower cane girth in $60 \mathrm{~cm}$ spaced planting might be due to reduced photosynthesis rate due to less light penetration and less utilization of nutrients. Our results are in agreement with those of [14] [15] who reported thicker canes in wider trench spacings.

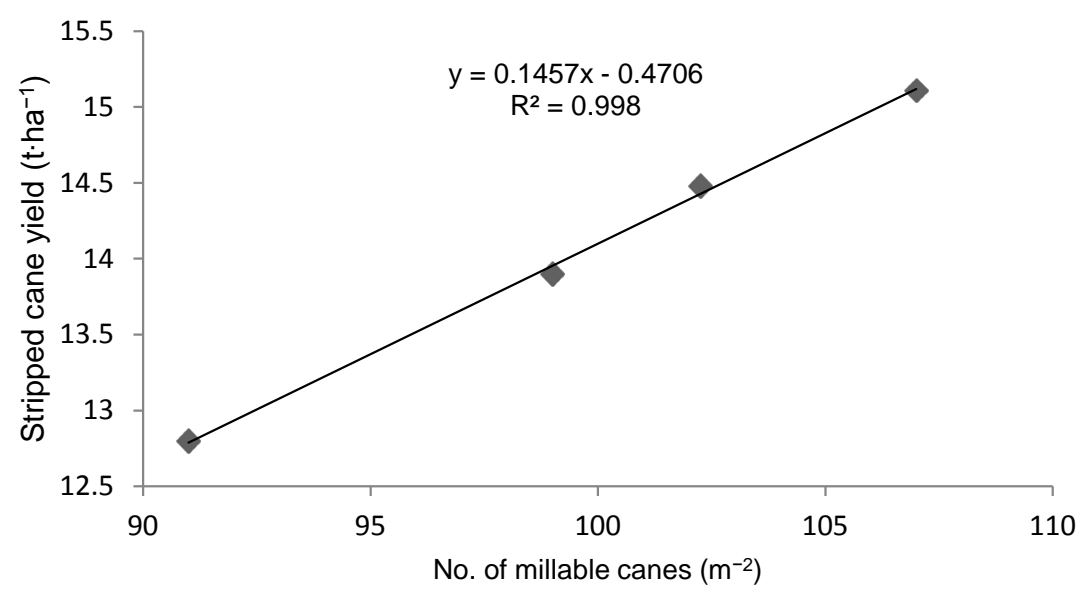

Figure 1. Influence of millable cane on stripped cane yield.

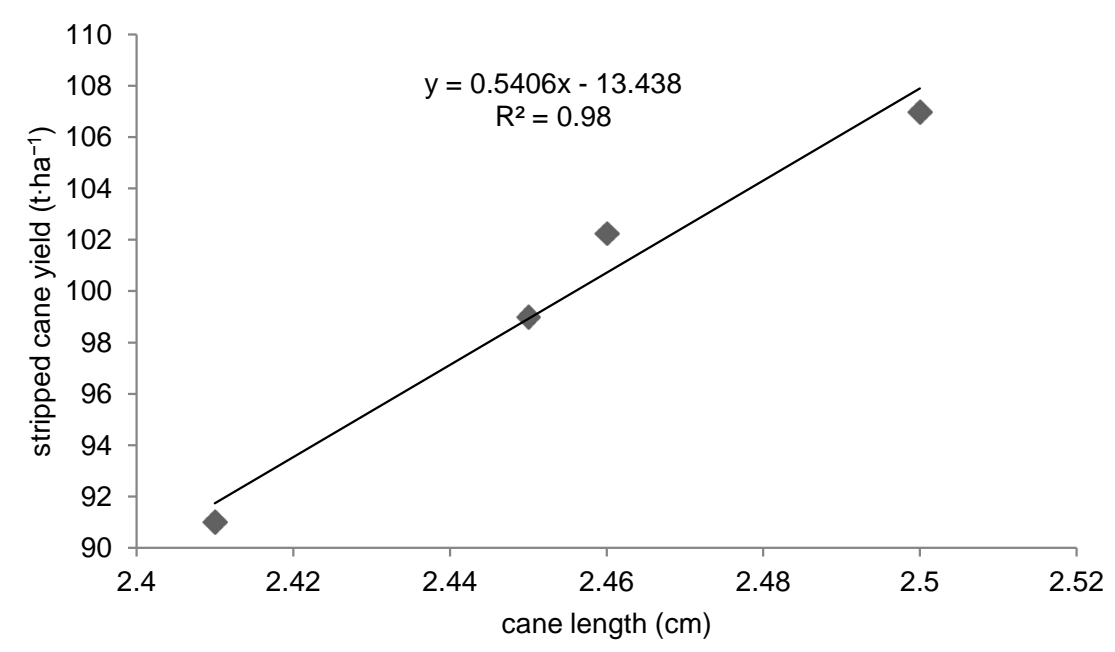

Figure 2. Influence of cane length on stripped cane yield. 


\subsection{Stripped Cane Yield ( $\mathrm{t} \cdot \mathrm{ha}^{-1}$ )}

It is cleared from the results that maximum yield $107 \mathrm{t} \cdot \mathrm{ha}^{-1}$ was recorded from $180 \mathrm{~cm}$ spaced trenches with triple row strips. $102 \mathrm{t} \cdot \mathrm{ha}^{-1}$ yield was recorded from $120 \mathrm{~cm}$ spaced trenches. While minimum yield $91 \mathrm{t} \cdot \mathrm{ha}^{-1}$ was recorded from $60 \mathrm{~cm}$ apart furrow as shown in Table 1. [7] [11] reported more cane yield was obtained from wider rows as compared to narrow rows. Regression model is indicated in Figure 3.

\subsection{Brix Percentage}

Cane maturity is commonly measured on the basis of brix degree. The perusal of data (Table 1) revealed that effect of different planting configurations on brix percentage was non-significant and the average ranged from $21.51 \%$ to $21.85 \%$. Non significant results might be ascribed to stable genetic character of the variety as well as similar environmental conditions, same date of sowing and harvesting, and similar nutrient management in the experimental field. Our findings are similar to [15] [16] they reported non-significant effect of row spacing on brix percentage.

\subsection{Polarity Percent}

Results depicted in Table 2 indicated non-significant variations in sucrose contents in all the treatments. Based on means, pol percentage ranged from $18.66 \%$ to $18.91 \%$ in different planting configurations. Non significant results might be ascribed to stable genetic character of the variety as well as similar environmental conditions, same date of sowing and harvesting, and similar nutrient management in the experimental field. Our results are in line with those of [7] [13] they manifested that different planting techniques did not affect polarity contents.

\subsection{Cane Juice Purity}

Data shown in Table 2 indicated that planting configurations failed to effect cane juice purity percentage. In different trenches and furrow, cane juice purity ranged from $86.19 \%$ to $86.85 \%$. As such, purity coefficient did not exhibit significant differences for varied row spacing. Non significant results might be ascribed to stable genetic character of the variety as well as similar environmental conditions, same date of sowing and harvesting, and similar nutrient management in the experimental field. Above results are in line with results of [13] [17]. While [18] also witnessed that purity was non-significantly affected by different row spacings.

\subsection{Cane Juice Percentage}

Perusal of data in Table 2 exhibited that planting configurations failed to effect cane juice percentage. On an average, cane juice percentage ranged from $69.7 \%$ to $70 \%$ in different row spacings. Juice extraction percentage

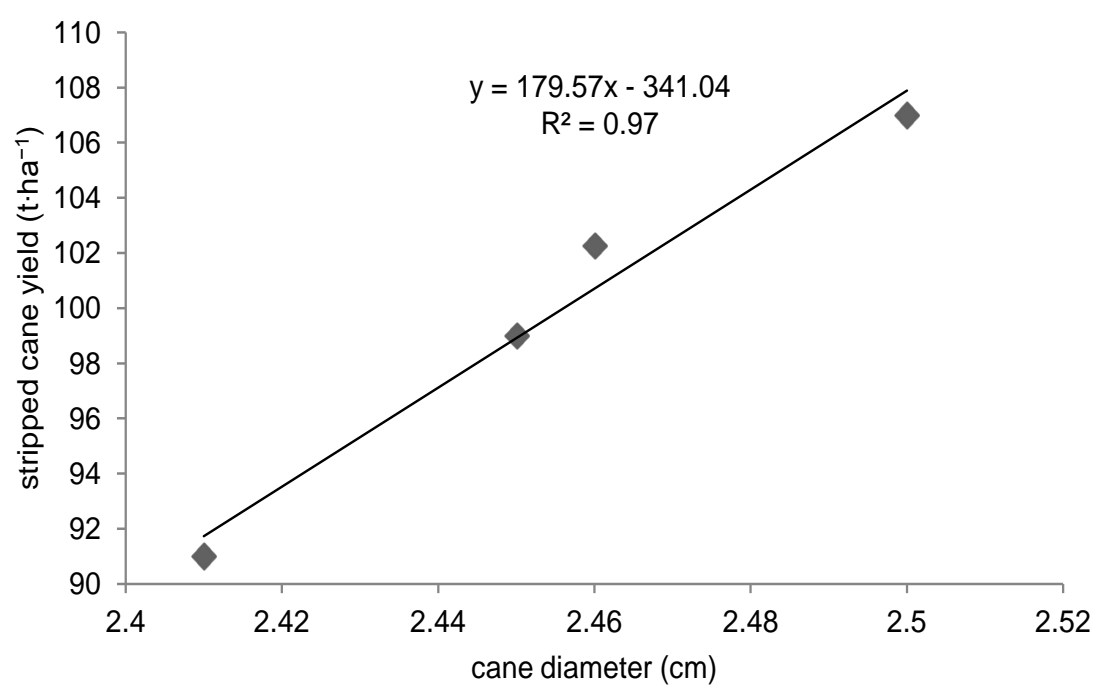

Figure 3. Influence of cane diameter on stripped cane yield. 
was not significantly affected by row spacing and seeding rates, although marginally higher values were recorded with wider row spacing and higher seeding rate [12]. These results are also in line with the findings of [17] who reported non-significant influence of sowing techniques on cane juice content.

\subsection{Commercial Cane Sugar}

CCS \% is one of the most aspects of cane quality the final goal to achieve optimum sugar yield. The real cane quality is reflected by its commercial cane sugar (CCS) percentage. Commercial cane sugar was not significantly affected by different planting geometry. Under different planting configurations commercial cane sugar (CCS \%) ranged from $14.03 \%$ to $14.18 \%$ (Table 2). Our results are similar to those of [7] [19] they stated that planting techniques failed to affect CCS \%.

\subsection{Cane Sugar Recovery}

Perusal of data manifested that different planting configurations failed to affect cane sugar recovery percentage. Data expressed in Table 2 exhibited that effect of different planting configurations on cane sugar recovery percentage was non-significant. However cane sugar recovery percent ranged from $13.12 \%$ to $13.33 \%$. [13] [15] also reported non-significant differences in sucrose contents by planting sugarcane either at wider or narrow row spacing.

Table 2. Effect of planting techniques on polarity, cane juice purity, cane juice \%, commercial cane sugar, cane sugar recovery, sugar yield.

\begin{tabular}{|c|c|c|c|c|c|c|}
\hline Treatments & $\begin{array}{c}\text { Polarity } \\
\text { (\%) }\end{array}$ & $\begin{array}{l}\text { Cane juice } \\
\text { purity (\%) }\end{array}$ & $\begin{array}{c}\text { Cane juice } \\
\text { (\%) }\end{array}$ & $\begin{array}{l}\text { Commercial cane } \\
\text { sugar }(\%)\end{array}$ & $\begin{array}{l}\text { Cane sugar } \\
\text { recovery }\end{array}$ & $\begin{array}{c}\text { Sugar yield } \\
\left(\mathbf{t} \cdot \mathbf{h a}^{-1}\right)\end{array}$ \\
\hline $\begin{array}{l}180 \mathrm{~cm} \text { spaced trenches } \\
\text { with triple row strips. }\end{array}$ & 18.91 & 86.56 & 70.00 & 14.17 & 13.32 & $15.11 \mathrm{~A}$ \\
\hline $\begin{array}{l}180 \mathrm{~cm} \text { spaced trenches } \\
\text { with alternate row strips. }\end{array}$ & 18.66 & 86.19 & 69.70 & 14.03 & 13.12 & $13.90 \mathrm{C}$ \\
\hline $\begin{array}{l}120 \mathrm{~cm} \text { spaced trenches } \\
\text { with double row strips. }\end{array}$ & 18.89 & 86.85 & 70.00 & 14.18 & 13.33 & $14.48 \mathrm{~B}$ \\
\hline $\begin{array}{l}60 \mathrm{~cm} \text { spaced furrow } \\
\text { with single row. }\end{array}$ & 18.76 & 86.67 & 69.72 & 14.07 & 13.23 & $12.80 \mathrm{D}$ \\
\hline LSD @ $\mathrm{P} \leq 0.05$ & NS & NS & NS & NS & NS & 0.30 \\
\hline
\end{tabular}

Letters A,B,C,D represents significant results. A means highest obtained value while D means lowest obtained value. A,B,C,D follows descending order in terms of values. $(\mathrm{A}>\mathrm{B}>\mathrm{C}>\mathrm{D})$.

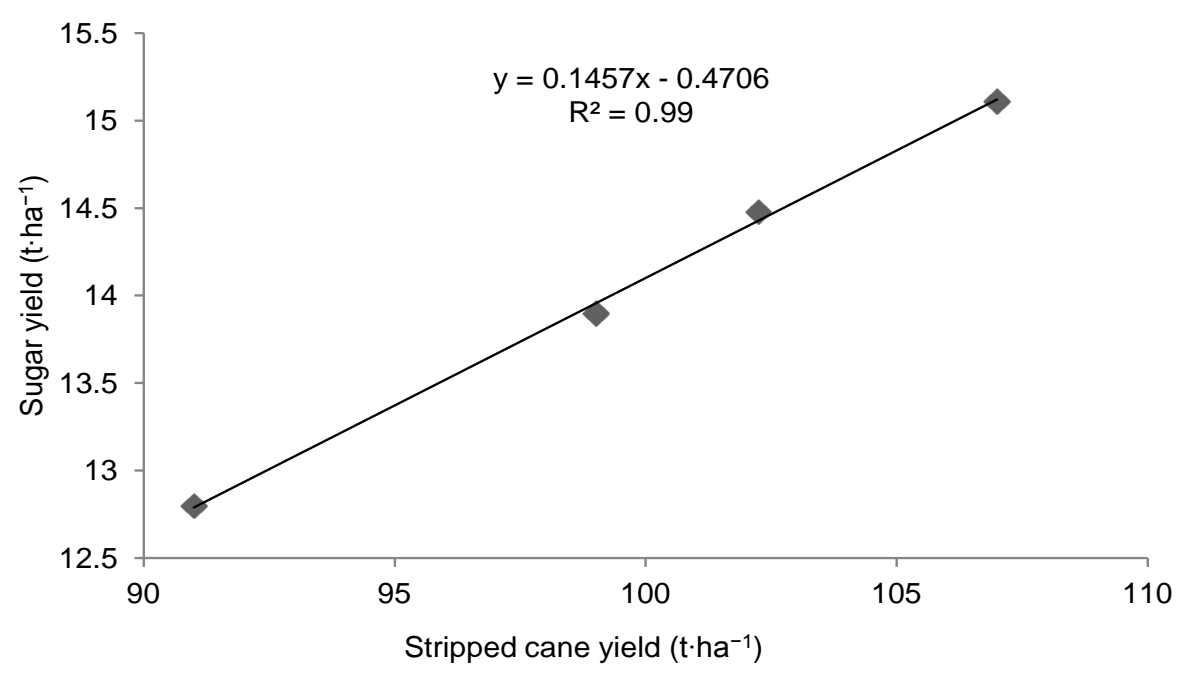

Figure 4. Influence of stripped cane yield on sugar yield. 


\subsection{Sugar Yield}

Perusal of data in Table 2 revealed that different planting methods significantly affected sugar yield. Cane sown in $180 \mathrm{~cm}$ spaced trenches with triple row strips gave highest total sugar yield $15.11 \mathrm{t} \cdot \mathrm{ha}^{-1}$. Cane sown at $120 \mathrm{~cm}$ spaced trenches gave sugar yield $14.48 \mathrm{t} \cdot \mathrm{ha}^{-1}$. Lowest sugar yield was manifested from $60 \mathrm{~cm}$ spaced furrow $12.80 \mathrm{t} \cdot \mathrm{ha}^{-1}$. The findings are similar to [13] [19]. They concluded that sugar yield was significantly higher in crop sown in wider spaced trenches. Regression model is indicated in Figure 4.

\section{Conclusion}

From above discussion, it is concluded that $180 \mathrm{~cm}$ spaced trenches with triple row strips is the most suitable planting method for sugarcane. Planting methods had non-significant results on quality parameters like brix \%, polarity \%, cane juice purity \%, cane juice $\%$, commercial cane sugar $\%$ and cane sugar recovery $\%$.

\section{References}

[1] Govt. of Pakistan (2015) Pakistan Economic Survey 2013-14. Ministry of Food Agriculture and Livestock, Federal Bureau of Stat., Islamabad, 27.

[2] FAO Stat. (2012) Statistical Database. Food and Agriculture Organization (FAO), Rome. http://faostat.fao.org/site/339/default.aspx

[3] Nazir, M.S. (1994) Sugarcane. In: Bashir, E. and Bantel, R., Eds., Crop Production, National Book Foundation, Islamabad, Pakistan, 421-422.

[4] Baloch, S.M., Shah, I.H., Hussain, I. and Abdullah, K. (2002) Low Sugar Production in Pakistan Causes and Remedies. Pakistan Sugar Journal, 17, 13-14.

[5] Malik, K.B. and Gurmani, M.H. (2005) Cane Production Guide. Dewan Farooque Sugarcane Research Institute, Dewan City, 38-41.

[6] Majid, A. (2007) Sugarcane Variety Composition in Pakistan. Pak. Sugar J, 22, 2-21.

[7] Ullah, E., Jabran, K., Jamil, M. and Ghaffar, A. (2011) Optimizing the Sugarcane Row Spacing and Seeding Density to Improve Its Yield and Quality. Crop and Environment, 2, 1-5.

[8] Chattha, M.U., Ali, A. and Bilal, M. (2007) Influence of Planting Techniques on Growth and Yield of Spring Planted Sugarcane (Saccharum officinarum L.). Pakistan Journal of Agricultural Sciences, 44, 452-456.

[9] Spancer, G.L. and Meade, G.P. (1963) Cane Sugar Hand Book. 9th Edition, John Wiley and Sons, Inc., New York, 17.

[10] Steel, R.G.D., Torrie, J.H. and Dicky, D.A. (1997) Principles and Procedures of Statistics, A Biometrical Approach. 3rd Edition, McGraw Hill, Inc. Book Co., New York, 352-358.

[11] Zafar, M., Tanveer, A., Cheema, Z.A. and Ashraf, M. (2010) Weed-Crop Competition Effects on Growth and Yield of Sugarcane Planted Using Two Methods. Pakistan Journal of Botany, 42, 815-823.

[12] Chattha, M.U. (2007) Studies on Growth, Yield and Quality of Sugarcane (Saccharum officinarum L.) under Different Planting Techniques, Irrigation Methods, Water Levels and Mulch Types. PhD Thesis, Department of Agronomy, University of Agriculture, Faisalabad, Pakistan.

[13] Ghaffar, A., Akbar, E.N. and Khan, S.H. (2011) Influence of Zinc and Iron on Yield and Quality of Sugarcane Planted under Various Trench Spacings. Pakistan Journal of Agricultural Sciences, 48, 25-33.

[14] Ghaffar, A. (2011) Influence of Zinc and Iron on Yield and Quality of Sugarcane Planted under Various Trench Spacings. PhD Thesis, Department of Agronomy, University of Agriculture, Faisalabad, Pakistan.

[15] Ruk, A.S., Kandhro, M.N., Baloch, S.K., Baloch, S. and Baloch, A.B. (2014) Impact of Sett Placement Methods and Row Direction Growth and Yield of Sugarcane Variety LRK-2001. Persian Gulf Crop Protection, 3, 53-69.

[16] Maqsood, M., Iqbal, M. and Tayyab, M. (2005) Comparative Productivity Performance of Sugarcane (Saccharum officinarum L.) Sown in Different Planting Patterns at Farmer’s Field. Pakistan Journal of Agricultural Sciences, 42, 3-4.

[17] Tej, P., Singh, R. and Singh, P.P. (2006) Studies on the Effect of Row Spacing, Seed Rate and Fertility Levels on Growth and Yield of Sugarcane (Saccharum officinarum L.). Indian Sugar, 56, 29-34.

[18] Jawad, H. (2014) Optimizing the Pit Dimensions and Geometry in Spring Planted Sugarcane. MSc (Hons.) Thesis, Department of Agronomy, University of Agriculture, Faisalabad, Pakistan.

[19] Sajjad, M., Bari, A., Nawaz, M. and Iqbal, S. (2014) Effect of Planting Pattern and Nutrient Management on Yield of Spring Planted Sugarcane. Sarhad Journal of Agriculture, 30, 67-71. 


\section{Submit or recommend next manuscript to SCIRP and we will provide best service for you:}

Accepting pre-submission inquiries through Email, Facebook, LinkedIn, Twitter, etc.

A wide selection of journals (inclusive of 9 subjects, more than 200 journals)

Providing 24-hour high-quality service

User-friendly online submission system

Fair and swift peer-review system

Efficient typesetting and proofreading procedure

Display of the result of downloads and visits, as well as the number of cited articles

Maximum dissemination of your research work

Submit your manuscript at: http://papersubmission.scirp.org/ 